IOSR Journal of Pharmacy

e-ISSN: 2250-3013, p-ISSN: 2319-4219, www.iosrphr.org

Volume 2 Issue 6 || || Nov-Dec. 2012 || | PP.36-41

\title{
Effect of graded levels of zinc supplementation on growth performance and oxidative defense mechanism in rats
}

\author{
D. Nagalakshmi ${ }^{1}$, S. Parashu Ramulu ${ }^{2}$, M. Usha Rani ${ }^{3}$ \\ College of Veterinary Science, Rajendranagar, Hyderabad, \\ Sri Venkateswara Veterinary University, India- 500030 \\ $\left({ }^{1}\right.$ Associate Professor, Department of Animal Nutrition, ) \\ $\left({ }^{2}\right.$ MVSc Student, Department of Animal Nutrition, $)$ \\ $\left({ }^{3}\right.$ Assistant Professor, Department of Veterinary Pharmacology and Toxicology, )
}

\begin{abstract}
A study was study wasundertaken to investigate the effect of graded levels of inorganic Zn (zinc carbonate) on growthperformance and oxidative defense mechanism inweaned female Sprague Dawley rats for experimental duration of 16 weeks. Ninety weaned rats $(93.83 \pm 1.308 \mathrm{~g} B \mathrm{wt})$ were randomly allotted to 30 replicates with 3 rats in each replicate which were in turn randomly allotted to 5 dietary treatments consisted of supplementing 0, 12, 24, 36 and 48 ppm Zinc carbonate to a basal diet(BD)formulated with purified ingredients without zinc. The zinc supplemented rats showedsignificant $(P<0.01)$ improvement in average daily gain without variation in dose of zinc supplementation.In comparison to basal diet, the feed intake in $Z n$ supplemented rats was significantly $(P<0.01)$ higher from the 4th week and similar trend continued till the end. The lipid peroxidation was higher $(P<0.01)$ in rats fed diet with no zinc supplement. The oxidative stress markers in haemolysate (lipid peroxidation) and liver (TBARS and protein carbonyls) was higher $(P<0.01)$ in $B D$ fed rats and their concentration reduced with $\mathrm{Zn}$ supplementation in a dose dependent manner up to 36ppm, while with 48ppm it increased. The reduced glutathione concentration in liver was lower $(P<0.01)$ in rats fed BD and 48ppmZnsupplemented rats, while it increased gradually from 12 to 36ppm $\mathrm{Zn}$ supplementation. The activity of glutathione peroxidase and reductase was highest in 36 and $48 \mathrm{ppm} \mathrm{Zn}$ supplemented rats followed by rats fed on 24 and 12 ppm zinc supplementation and BD. It indicates that Supplemental $\mathrm{Zn}$ at 12, 24, 36 and 48ppm was effective in improving the growth performance, feed intake and oxidative defense except 48 ppm $\mathrm{Zn}$ had negative effect on antioxidant activity.
\end{abstract}

Keywords-Antioxidants, feed intake, growth, rats, zinc.

\section{INTRODUCTION}

Zinc is an essential trace element for human as well as animals, and it exerts various physiological functions that influence the growth, healthand reproduction in different ways. Zinc is an intracellular signaling molecule and plays an important role in antioxidantmechanism through number of proposed mechanisms [1]. This is the unique property of zinc that may have significant therapeutic benefits in several diseases in humans and livestock. In many diseases concurrent zinc deficiency may causes complication of clinical features by increasing the oxidative stress [2] sinceexcess accumulation of free radicals than that can be handled by antioxidant enzymes can lead to chronic disorders in livestock as well as human.Though $\mathrm{Zn}$ is an essential micronutrient, the use of $\mathrm{Zn}$ supplement has been discouraged by some health professional because excessive intake of $\mathrm{Zn}$ has been reported to induce $\mathrm{Cu}, \mathrm{Mg}, \mathrm{Mn}, \mathrm{Fe}$ and Se deficiencies due their antagonistic interactions [3] as these minerals are required as cofactor for optimum catalytic activities and effective antioxidant defense mechanism of the body.

Hence, regardless of how these highly reactive oxygen species are generated, they must be dealt with in order to maintain good health and optimal productivity. Hence, our present investigation was carried out to know the influence of levels of zinc supplementation on growth performance and oxidative defense mechanism in rats.

\section{MATERIAL AND METHODS}

A study was conducted on 90 weaned female Sprague Dawley rats (SD) strain with an average body weight of $93.83 \pm 1.308 \mathrm{~g}$. The rats were housed in polypropylene cages in the Animal House of College of Veterinary Science, Hyderabad under hygienic conditions with controlled temperature $\left(22-23^{\circ} \mathrm{C}\right)$ and photoperiod $(12 \mathrm{~h} / \mathrm{d})$. The rearing and care of rats and procedures adopted were according to the guidelines of 
Institutional Animal Ethics Committee. The rats were provided with respective diet adlibitum and with free access to wholesome clean deionisedwater. Water was provided in polypropylene bottles having provision for nipples.The animals were randomly divided into 30 replicates with 3 rats per replicate and these 30 replicates in turn were randomly allotted to 5 dietary treatments and were fed with the respective diets for an experimental duration of 16 weeks. A basal diet (BD) based on AIN- 76A rodent diet for growing rats was formulated without any $\mathrm{Zn}$ supplement using purified ingredients (Table 1) as a control diet. The other 4 diets were $\mathrm{Zn}$ supplemented diets in which $\mathrm{Zn}$ was supplemented to BD in the form of $\mathrm{Zn}$ carbonate to supply 12, 24, 36 and $48 \mathrm{ppm}$ of $\mathrm{Zn}$. During experimentation, weekly body weights and daily feed intake were recorded. On $83^{\text {rd }}$ $\mathrm{d}$ of the experiment, blood was collected to assess the antioxidant enzymes. After 16weeks of feeding trial, one rat per replicate was sacrificed and liver was collected for determining antioxidant enzymes activity in liver.

Table 1 Ingredient composition of Purified diet (AIN-76A)

\begin{tabular}{|ll|}
\hline Ingredient & Proportion, g/kg diet \\
\hline Casein & 500.0 \\
\hline Corn starch & 200.0 \\
\hline Oil & 150.0 \\
\hline Cellulose & 50.0 \\
\hline Mineral mixture* & 50.0 \\
\hline Vitamin mixture* & 35.0 \\
\hline DL-methionine & 10.0 \\
\hline Choline chloride & 3.0 \\
\hline$*$ Minal anv & 2.0 \\
\hline
\end{tabular}

*Mineral and vitamin mixture was prepared as per specifications for AIN-76A

\subsection{Oxidative stress markers and antioxidant enzyme activity in haemolysate}

The blood collected in clean heparinized vacutainers was centrifuged at $2000 \mathrm{rpm}$ for 15 minutes at $4^{\circ} \mathrm{C}$ to separate buffy coat and erythrocyte pellet. The erythrocytes were washed thrice with phosphate buffer saline (PH 7.4). The packed RBC obtained was mixed with an equal volume of phosphate buffer saline and then diluted as per requirement with distilled water.

The oxidative enzymes viz., RBC catalase, lipid peroxidation (LPx), glutathione peroxidase and glutathione reductase in haemolysate were estimated asper the procedures of Bergmeyer[4], Placer [5], Paglia and Valantine [6] andMannervik [7] respectively and the enzyme activity was expressed as units per $\mathrm{g} \mathrm{Hb}$, nmol $\mathrm{MDA} / \mathrm{g} \mathrm{Hb}, \mu \mathrm{M} / \mathrm{mg}$ protein and $\mu \mathrm{M} / \mathrm{mg}$ protein, respectively. The Hband protein concentration in haemolysate was estimated colorimetricallyas per the procedure described by Cannan[8] and Lowry [9].

\subsection{Oxidative stress markers in liver}

After 16 weeks of experiment, one rat per replicate was sacrificed. Immediately after slaughter, liver was removed and perfused with normal saline $(0.9 \%)$ to reduce red blood cell contamination. The samples were then fixed in liquid nitrogen and stored at $-20^{\circ} \mathrm{C}$ for antioxidant analysis. The markers Thiobarbituric acid reacting substances (TBARS), reduced glutathione (GSH)and protein carbonyls were estimated as per the procedures of Balasubramanian[10], Moron [11] and Levine [12], respectively and was expressed as nmole per $\mathrm{mg}$ protein, $\mu \mathrm{M} \mathrm{GSH} / \mathrm{mg}$ of protein and nmole per mg protein, respectively.

2.3 Statistical analysis

The results obtained were statistically analyzed by using one way ANOVA according to the method of Snedecor and Cochran [13]. The means were compared by Duncan's multiple range test [14].

\subsection{Effect of zinc on body weight and feed intake}

\section{RESULTS AND DISCUSSION}

No effect of zinc supplementation was observed on body weight of rats up to $3^{\text {rd }}$ week of study, while from $4^{\text {th }}$ week onwards, dietary zinc supplementation had influence on weekly body weights. The body weight during $4^{\text {th }}$ week was higher $(\mathrm{P}<0.01)$ in zinc supplemented rats than BD fed rats and similar trend continued till the end of the feeding trial i.e. up to 16 weeks. Further this was reflected in average daily gain (ADG) which improved $(\mathrm{P}<0.01)$ with $\mathrm{Zn}$ supplementation. Among the $\mathrm{Zn}$ supplemented rats, no effect of $\mathrm{Zn}$ concentration $(12-48 \mathrm{ppm})$ was observed on body weights and average daily gain. 
Similar to body weight changes, the feed intake was comparable among rats of various groups up to $4^{\text {th }}$ week and influence of $\mathrm{Zn}$ supplementation was observed from $4^{\text {th }}$ week. During the 4 th $(\mathrm{P}<0.01)$ and 5 th $(\mathrm{P}<0.05)$ week the feed intake was higher in rats fed 12 or $24 \mathrm{ppm}$ zinc compared to BD fed rats and similar pattern was observed till the end of $16^{\text {th }}$ week. The feed intake in rats fed on $48 \mathrm{ppm} \mathrm{Zn}$ diet was comparable to that of BD, but later it increased by the end of 16 weeks and was similar to the intake of other $\mathrm{Zn}$ supplemented rats (12-36 ppm).These results were in agreement with Sahin and Kucuk [15], who observed increased feed intake $(\mathrm{P}<0.01)$ in $\mathrm{Zn}$ supplemented quails $(30$ and $60 \mathrm{ppm})$ compared to unsupplemented group.

In the present investigation, retardation of growth in the BD group might be due to impairment of zinc dependent enzymes that influence the cell proliferation and DNA replication but not due to decreased feed intake. The improved ADG in zinc supplemented groups is consistent with the reports of Taneja[16] and Singh [17] in rats, who observed improved growth rate in rats fed basal diet containing $20 \mathrm{ppm} \mathrm{Zn}$ as $\mathrm{ZnSO}_{4} .7 \mathrm{H}_{2} \mathrm{O}$ throughout the experimental period (180 days), and growth ratereducedin 40 and 80ppm supplemented diets fed rats after 150 days of experiment. In present study, no such growth depression was observed in 36 and 48 ppm Zn supplemented rats. Similarly several authors reported that rats fed zinc deficient diets gained 25\% [18] and $11 \%$ [19]lower weightthan the zinc supplemented $(30 \mathrm{mg} / \mathrm{kg}$ diet and $40 \mathrm{mg} / \mathrm{l}$, per osrespectively) rats.In present investigation, the lower feed intake with $48 \mathrm{ppm}$ supplementation up to $15^{\text {th }}$ week, suggested that higher concentration of $\mathrm{ZnSO}_{4}$ could have a negative influence on feed intake.

\subsection{Effect of zinc on antioxidant enzymes and oxidative stress markers}

Lipid peroxidation is a free radical mediated chain reaction, is treated as best marker of oxidative stress [20]as its concentration increases during oxidative stress. Though it is a self perpetuating reaction its propagation can be arrested by chain breaking antioxidant. The results in the present study indicated that oxidative stress was higher in zinc deficient rats and was alleviated with Zn supplementation (Table4 and 5). The lipid peroxidation was higher $(\mathrm{P}<0.01)$ in rats fed diet with no zinc supplement. Supplementation of $12 \mathrm{ppm}$ $\mathrm{Zn}$ reduced the lipid peroxidation, but the affect was not significant, while lipid peroxidation was lowered in rats fed on 24 and 36ppm Zn. It implies that $\mathrm{Zn}$ had an ameliorative effect on lipid peroxidation, while peroxidation was increased with 48ppm of $\mathrm{Zn}$ supplementation. Similarly, the TBARS and protein carbonyls concentration in liver indicative of oxidative stress was lower $(\mathrm{P}<0.05)$ in $\mathrm{Zn}$ supplemented rats compared to unsupplemented ones. Among the zinc supplemented rats, the TBARS and protein carbonyls content was lowest $(\mathrm{P}<0.05)$ in rats fed $36 \mathrm{ppm} \mathrm{Zn}$ followed by $24 \mathrm{ppm} \mathrm{Zn}$ supplementation, and the concentration in liver of $48 \mathrm{ppm} \mathrm{Zn}$ supplemented rats was higher $(\mathrm{P}<0.05)$ compared to $\mathrm{Zn}$ supplementation at lower concentration $(12-36 \mathrm{ppm})$.

The reduced glutathione concentration in liver was lower $(\mathrm{P}<0.01)$ in $\mathrm{Zn}$ deficient rats and increased gradually with 12 to $36 \mathrm{ppm} \mathrm{Zn}$ supplementation (Table 5). The concentration of reduced glutathione was highest on 36ppm $\mathrm{Zn}$ supplementation and thereafter its concentration gradually decreased with $48 \mathrm{ppm} \mathrm{Zn}$ addition. Similarly,glutathione peroxidase activity was higher $(\mathrm{P}<0.05)$ in rats fed $\mathrm{Zn}$ supplemented dietsthan rats fed on BD. Among the Zn supplemented rats highest activity of glutathione peroxidase was observed with 48 ppm supplementation followed by 36,24 and $12 \mathrm{ppm}$ supplementation in a dose dependent manner.

The increased levels of oxidative stress markers in zinc deficient rats and improvement in antioxidant enzyme activity, with reduced lipid peroxiadtion in the present investigation with Zn supplementation in dose dependent manner was observed up to $36 \mathrm{ppm}$ zinc supplementation. However, the reverse observed in $48 \mathrm{ppm}$ $\mathrm{Zn}$ supplemented group might be due hyper zinccaemea or due to altered $\mathrm{Cu}-\mathrm{Zn}$ ratio. Though zinc is an essential trace element,there are some evidences that excess zinc can cause enhanced oxidative stress [21].The activities of $\mathrm{Cu}$ and $\mathrm{Zn}$ containing antioxidant enzymes including superoxide dismutase (SOD), cyto-chrome-C oxidase (CCO), catalase (CAT) and gluta- thione peroxidase (GPx) have been reported to diminish under $\mathrm{Zn}$ or $\mathrm{Cu}$-deficiency or due to alteration in $\mathrm{Cu}-\mathrm{Zn}$ ratio [22,23, 24].Similar to present investigation, Singh, [17] reported that supplementation of excess zinc ( 40 and $80 \mathrm{ppm} \mathrm{Zn}$ as $\mathrm{ZnSO}_{4} .7 \mathrm{H}_{2} \mathrm{O}$ ) in rats resulted in significant $(\mathrm{P}$ $<0.01)$ increase in oxidative stress markers (LPx) in liver and kidney than in the control group supplemented with 20ppm. Further, their high concentration in excess zinc supplemented groups coincided with enzymes of antioxidant defense system i.e. SOD, CAT, glutathione-s-transferase, glutathione reductase, GSH and glucose6-phosphate dehydrogenase whose activities were evaluated significantly less $(\mathrm{P}<0.01 ; \mathrm{P}<0.05)$ in these groups after six months of dietary treatment. Several researchers reported that a deficiency of zinc led to lipid peroxidation in various tissues [25,26]. It was shown that zinc deficiency caused or increased oxidative stress in rat testicles [27], kidney [28], liver [29], and brain [30]. Similarly ameliorative effect of zinc against oxidative stress in rats was reported by several authors, who induced the stress artificially using electromagnetic field [31], cadmium [19], alloxan[32], carbon tetra chloride [33] and burns[34].

\section{CONCLUSION}

Supplemental $\mathrm{Zn}$ at 12, 24 and $36 \mathrm{ppm}$ was effective in improving the oxidative defense mechanism in a dose dependent manner. Improvement in growth rate and feed intake was observed with $12 \mathrm{ppm} \mathrm{Zn}$ supplementation, while $\mathrm{Zn}$ supplementation at 24-48 ppm had no further improvement on growth performance. 
The supplementation of $48 \mathrm{ppm} \mathrm{Zn}$ had negative effect on antioxidant activity. It indicates that supplemental zinc above AIN-76A recommended $\mathrm{Zn}$ concentration $(36 \mathrm{ppm})$ had negative influence on oxidative defense mechanism without affecting growth performance and feed intake. Hence it shows that judicial concentration of dietary $\mathrm{Zn}$ must be essential in improving the health condition in humans and livestock.

Table 2: Body weight changes (g) in rats fed diets varying in zinc concentration

\begin{tabular}{|c|c|c|c|c|c|c|c|}
\hline \multirow[t]{2}{*}{ Week } & \multicolumn{5}{|c|}{ Zinc supplementation in ppm } & \multirow[t]{2}{*}{ SEM } & \multirow[t]{2}{*}{$P$ value } \\
\hline & $\mathbf{0}$ & 12 & 24 & 36 & 48 & & \\
\hline Start & 93.83 & 93.83 & 93.83 & 93.83 & 94.18 & 1.321 & 0.999 \\
\hline 1 & 117.0 & 113.7 & 123.5 & 115.6 & 116.7 & 1.629 & 0.392 \\
\hline 2 & 139.2 & 143.4 & 151.1 & 146.2 & 148.4 & 1.647 & 0.222 \\
\hline 3 & 160.6 & 165.5 & 171.2 & 168.3 & 170.3 & 1.717 & 0.284 \\
\hline 4 & $163.5^{b}$ & $188.3^{\mathrm{a}}$ & $190.1^{\mathrm{a}}$ & $183.7^{\mathrm{a}}$ & $188.9^{\mathrm{a}}$ & 2.614 & 0.004 \\
\hline 5 & $178.6^{\mathrm{b}}$ & $199.3^{\mathrm{a}}$ & $205.8^{\mathrm{a}}$ & $201.4^{\mathrm{a}}$ & $202.7^{\mathrm{a}}$ & 2.694 & 0.008 \\
\hline 6 & $190.6^{\mathrm{b}}$ & $213.8^{\mathrm{a}}$ & $217.8^{\mathrm{a}}$ & $213.2^{\mathrm{a}}$ & $216.1^{\mathrm{a}}$ & 2.879 & 0.013 \\
\hline 7 & $200.6^{b}$ & $225.6^{\mathrm{a}}$ & $225.0^{\mathrm{a}}$ & $226.2^{\mathrm{a}}$ & $223.3^{\mathrm{a}}$ & 2.892 & 0.017 \\
\hline 8 & $208.1^{\mathrm{a}}$ & $233.2^{\mathrm{b}}$ & $228.4^{\mathrm{b}}$ & $235.6^{\mathrm{b}}$ & $220.5^{\mathrm{ab}}$ & 2.966 & 0.019 \\
\hline 9 & $212.3^{b}$ & $238.9^{\mathrm{a}}$ & $235.2^{\mathrm{a}}$ & $238.1^{\mathrm{a}}$ & $225.3^{\mathrm{a}}$ & 2.985 & 0.018 \\
\hline 10 & $220.9^{b}$ & $246.7^{\mathrm{a}}$ & $242.7^{\mathrm{a}}$ & $245.2^{\mathrm{a}}$ & $241.6^{\mathrm{a}}$ & 3.078 & 0.047 \\
\hline 11 & $222.9^{b}$ & $251.3^{\mathrm{a}}$ & $247.6^{\mathrm{a}}$ & $249.4^{\mathrm{a}}$ & $247.9^{\mathrm{a}}$ & 3.134 & 0.019 \\
\hline 12 & $222.9^{\mathrm{b}}$ & $247.1^{\mathrm{a}}$ & $253.2^{\mathrm{a}}$ & $248.3^{\mathrm{a}}$ & $247.4^{\mathrm{a}}$ & 3.276 & 0.025 \\
\hline 13 & $229.6^{b}$ & $254.9^{\mathrm{a}}$ & $261.8^{\mathrm{a}}$ & $258.3^{\mathrm{a}}$ & $250.5^{\mathrm{a}}$ & 3.237 & 0.011 \\
\hline 14 & $216.7^{b}$ & $257.9^{\mathrm{a}}$ & $264.7^{\mathrm{a}}$ & $264.7^{\mathrm{a}}$ & $261.3^{\mathrm{a}}$ & 4.452 & 0.002 \\
\hline 15 & $213.4^{b}$ & $261.2^{\mathrm{a}}$ & $262.3^{\mathrm{a}}$ & $262.8^{\mathrm{a}}$ & $258.2^{\mathrm{a}}$ & 4.469 & 0.001 \\
\hline 16 & $213.8^{b}$ & $256.9^{\mathrm{a}}$ & $263.0^{\mathrm{a}}$ & $260.2^{\mathrm{a}}$ & $264.5^{\mathrm{a}}$ & 4.622 & 0.001 \\
\hline $\begin{array}{l}\text { Total } \\
\text { gain }\end{array}$ & $120.0^{b}$ & $163.1^{\mathrm{a}}$ & $169.2^{\mathrm{a}}$ & $165.2^{\mathrm{a}}$ & $170.3^{\mathrm{a}}$ & 4.763 & 0.002 \\
\hline ADG & $7.50^{\mathrm{b}}$ & $10.19^{\mathrm{a}}$ & $10.57^{\mathrm{a}}$ & $10.32^{\mathrm{a}}$ & $10.65^{\mathrm{a}}$ & 0.298 & 0.002 \\
\hline
\end{tabular}

Table 3: Daily feed intake in rats fed diets varying in zinc concentration

\begin{tabular}{|c|c|c|c|c|c|c|c|}
\hline \multirow[t]{2}{*}{ Week } & \multicolumn{5}{|c|}{ Zinc supplementation in ppm } & \multirow[t]{2}{*}{ SEM } & \multirow[t]{2}{*}{ P value } \\
\hline & $\mathbf{0}$ & 12 & 24 & 36 & 48 & & \\
\hline 1 & 8.91 & 7.91 & 9.33 & 7.98 & 8.64 & 0.199 & 0.103 \\
\hline 2 & 11.11 & 11.79 & 11.61 & 12.64 & 12.32 & 0.275 & 0.452 \\
\hline 3 & 10.82 & 12.56 & 11.90 & 11.87 & 11.49 & 0.200 & 0.073 \\
\hline 4 & $11.48^{\mathrm{b}}$ & $12.99^{\mathrm{a}}$ & $13.29^{\mathrm{a}}$ & $12.08^{\mathrm{b}}$ & $11.98^{\mathrm{b}}$ & 0.164 & 0.001 \\
\hline 5 & $11.38^{b}$ & $13.13^{\mathrm{a}}$ & $13.02^{\mathrm{a}}$ & $12.68^{\mathrm{ab}}$ & $12.44^{\mathrm{ab}}$ & 0.221 & 0.049 \\
\hline 6 & $10.91^{b}$ & $12.56^{\mathrm{a}}$ & $12.52^{\mathrm{a}}$ & $12.61^{\mathrm{a}}$ & $11.30^{b}$ & 0.206 & 0.006 \\
\hline 7 & $10.75^{b}$ & $12.89^{\mathrm{a}}$ & $13.05^{\mathrm{a}}$ & $13.02^{\mathrm{a}}$ & $12.27^{\mathrm{ab}}$ & 0.277 & 0.030 \\
\hline 8 & $10.99^{\mathrm{bc}}$ & $13.33^{\mathrm{a}}$ & $12.18^{\mathrm{ab}}$ & $12.86^{\mathrm{a}}$ & $9.95^{\mathrm{c}}$ & 0.327 & 0.001 \\
\hline 9 & $11.70^{b}$ & $14.01^{\mathrm{a}}$ & $13.11^{\mathrm{ab}}$ & $12.48^{\mathrm{ab}}$ & $11.49^{b}$ & 0.287 & 0.021 \\
\hline 10 & $11.96^{\mathrm{b}}$ & $13.46^{\mathrm{b}}$ & $16.53^{\mathrm{a}}$ & $12.53^{\mathrm{b}}$ & $12.89^{b}$ & 0.373 & 0.001 \\
\hline 11 & $11.17^{b}$ & $12.69^{\mathrm{ab}}$ & $13.77^{\mathrm{a}}$ & $12.76^{\mathrm{ab}}$ & $12.03^{\mathrm{ab}}$ & 0.288 & 0.048 \\
\hline 12 & $10.85^{b}$ & $12.42^{\mathrm{ab}}$ & $12.20^{\mathrm{ab}}$ & $12.76^{\mathrm{a}}$ & $11.08^{b}$ & 0.254 & 0.048 \\
\hline 13 & $11.41^{b}$ & $13.03^{\mathrm{a}}$ & $13.63^{\mathrm{a}}$ & $12.17^{\mathrm{ab}}$ & $12.18^{\mathrm{ab}}$ & 0.242 & 0.027 \\
\hline 14 & $10.72^{b}$ & $12.69^{\mathrm{a}}$ & $13.22^{\mathrm{a}}$ & $12.41^{\mathrm{a}}$ & $12.08^{\mathrm{ab}}$ & 0.265 & 0.027 \\
\hline 15 & $9.48^{b}$ & $11.82^{\mathrm{a}}$ & $11.44^{\mathrm{ab}}$ & $10.44^{\mathrm{a}}$ & $10.59^{\mathrm{ab}}$ & 0.284 & 0.046 \\
\hline 16 & $9.06^{b}$ & $11.75^{\mathrm{a}}$ & $11.44^{\mathrm{a}}$ & $11.75^{\mathrm{a}}$ & $11.01^{\mathrm{a}}$ & 0.313 & 0.022 \\
\hline
\end{tabular}


Table 6: Oxidative enzyme activities in haemolysate of rats fed diets varying in zinc concentration

\begin{tabular}{|c|c|c|c|c|c|c|c|}
\hline \multirow[t]{2}{*}{ Attribute } & \multicolumn{5}{|c|}{ Zinc supplementation in ppm } & \multirow[t]{2}{*}{ SEM } & \multirow[t]{2}{*}{$P$ value } \\
\hline & $\mathbf{0}$ & 12 & 24 & 36 & 48 & & \\
\hline $\begin{array}{l}\text { Lipid peroxidation (nM } \\
\text { MDA/g Hb) }\end{array}$ & $28.35^{\mathrm{a}}$ & $24.83^{\mathrm{ab}}$ & $13.92^{c}$ & $18.47^{\mathrm{bc}}$ & $24.40^{\mathrm{ab}}$ & 1.334 & 0.001 \\
\hline $\begin{array}{l}\text { Glutathione peroxidase } \\
\text { ( } \mu \mathrm{M} / \mathrm{mg} \text { protein) }\end{array}$ & $0.860^{c}$ & $1.246^{\mathrm{bc}}$ & $1.406^{\mathrm{b}}$ & $2.173^{\mathrm{a}}$ & $2.363^{\mathrm{a}}$ & 0.124 & 0.001 \\
\hline $\begin{array}{l}\text { Glutathione reductase } \\
\text { ( } \mu \mathrm{M} / \mathrm{mg} \text { protein) }\end{array}$ & $0.650^{b}$ & $0.958^{\mathrm{ab}}$ & $0.849^{b}$ & $1.273^{\mathrm{a}}$ & $0.964^{\mathrm{ab}}$ & 0.313 & 0.006 \\
\hline
\end{tabular}

${ }^{\mathrm{abc}}$ Means with different superscripts in a row differ significantly: $\mathrm{P}<0.01$

Table 7: TBARS, protein carbonyls and reduced glutathione concentration in liver of rats fed diets varying in zinc concentration

\begin{tabular}{|c|c|c|c|c|c|c|c|}
\hline \multirow[t]{2}{*}{ Attribute } & \multicolumn{5}{|c|}{ Zinc supplementation in ppm } & \multirow[t]{2}{*}{ SEM } & \multirow{2}{*}{$\begin{array}{l}\mathbf{P} \\
\text { valut }\end{array}$} \\
\hline & $\mathbf{0}$ & 12 & 24 & 36 & 48 & & \\
\hline $\begin{array}{l}\text { TBARS (nM MDA/mg } \\
\text { protein) }\end{array}$ & $0.020^{\mathrm{a}}$ & $0.018^{\mathrm{ab}}$ & $0.013^{\mathrm{bc}}$ & $0.010^{\mathrm{c}}$ & $0.016^{\mathrm{abc}}$ & 0.0010 & $\mathbf{0 . 0 3 0}$ \\
\hline $\begin{array}{l}\text { Protein carbonyls } \\
\text { (nM/mg protein) }\end{array}$ & $1.37^{\mathrm{a}}$ & $1.05^{\mathrm{bc}}$ & $1.05^{\mathrm{bc}}$ & $0.887^{\mathrm{c}}$ & $1.16^{\mathrm{ab}}$ & 0.045 & 0.049 \\
\hline $\begin{array}{l}\text { Reduced glutathione } \\
(\mu \mathrm{M} / \mathrm{mg} \text { protein) }\end{array}$ & $31.28^{\mathrm{c}}$ & $143.53^{b}$ & $101.07^{\text {bc }}$ & $278.93^{\mathrm{a}}$ & $34.15^{\mathrm{c}}$ & 19.951 & 0.001 \\
\hline
\end{tabular}

${ }^{\mathrm{abc}}$ Means with different superscripts in a row differ significantly: $\mathrm{P}<0.01 ; \mathrm{P}<0.05$

\section{REFERENCE}

[1]. S.R Powell,Antioxidant properties of zinc, Journal of Nutrition, 130, 2000, 1447-1454.

[2]. A.S Prasad, Impact of the discovery of human zinc deficiency on health, Journal of the American College of Nutrition, 28(3), 2009, 257-265.

[3]. J Aaseth, M. Haugen, and O.C. Forre,Rheumatoid arthritis and metalcomponents-perspective on the role of oxygen radical detoxification, Analyst, 123, 1998, 3-6.

[4]. H.U Bergmeyer, Catalase. Methods of enzymatic analysis, 2 (Weinheim, VerlagChemie, 1983) 165-166.

[5]. Z.A Placer, L.L Cushman, and B.C Johnson, Estimation of product of lipid peroxidation (MalonylDialdehyde) in biochemical systems. AnalyticalBiochemestry, 16, 1966, 359-364.

[6]. D.E Paglia, W.N Valentine, Studies on the quantitative and qualitative of erythrocyte glutathioneperoxidase, Journal of Laboratory and Clinical Medicine, 70, 1967, 158-168.

[7]. B Mannervik, and I Carlberg, Glutathione Reductase. Methods in Enzymology, 113, 1985, 484-490.

[8]. R.KCannan, LaboratoryMethods-Proposal for a certified standard for use in hemoglobinometry second and final report, Journal of Laboratory and Clinical Medicine,52(3), 1958, 471-476.

[9]. O.H Lowry, N.J Rosenberg, A.L Farr, and R.J Randal, Protein measurement with the Folin-Phenol reagent,Journal of Biological Chemistry, 193, 1951, 265-275

[10]. K.A Balasubramanian, M Manohar, and V.I Mathan, An unidentified inhibitor of lipid peroxidation in intestinal mucosa,Biochimica etBiophysicaActa,962, 1988, 51-58.

[11]. M.J Moron, J.W Diperre, andK.B Mannerv, Levels of glutathione, Glutathione reductase and Glutathione-stransferase activities in rat lungs and liver,Biochimica et Biophysica Acta,582, 1979, 67-71.

[12]. R.L Levine, D Garland, C.N Oliver, A Amici, I Climent, A.G Lenz, B.W Ahn, S Shaltiel, and E.R Stadtman, Determination of carbonyl content in oxdatively modified proteins,Methods in Enzymology. 186, 1990, 464-478.

[13]. G.W Snedecor, and W.G Cochran, Statistical methods (8th Ed. Iowa State Univ press Ames Iowa, USA, 1989)

[14]. D.B Duncan, Multiple range and multiple F-tests, Biometrics 11, 1955, 1-42.

[15]. K Sahin, andO Kucuk, Zinc Supplementation alleviates heat stress in laying Japanese quail. Journal of Nutrition, 133, 2003, 2808-2811

[16]. S.K Taneja, R Mandal, andS Girhotra, Long term excessive Zn supplementation promotes metabolic syndrome-X in wistar rats fed sucrose and fat rich semi-syntheticdiet, Indian Journal of Experimental Biology,44,2006,705-718.

[17]. K.B Singh, Long term excessive Zn supplementation induced oxidative stress in wistarrats fed on semi-synthetic diet,Food and Nutrition Sciences, 3, 2012, 724-731.

[18]. 18. A Kraus, H.P Roth, and M Kirchgessner, Supplementation with vitamin c, vitamin e or $\beta$-carotene influences osmotic fragility and oxidative damage of erythrocytes of zinc-deficient rats,Journal of Nutrition, 127, 1997, 12901296. 
[19]. S Amara, H Abdelmelek, C Garrel, P Guiraud, Q Douki, J Ravanat, A Favier, M Sakly, andK.B Rhouma, Preventive effect of zinc against cadmium-induced oxidative stress in the rat testis, Journal of Reproduction andDevelopement, 54, 2008, 2.

[20]. E.I Saygili, D Konukoglu, S Papila, andT Aksay, Levels of plasma vitamin E, vitamin C, TBARS and cholesterol in male patients with colorectal tumors, Biochemistry (Moscow), 68(3), 2003, 317.

[21]. H Yanagisawa, M Sato, M Nodera, and O Wada, Excessive zinc intake elevates systemic blood pressure levels in normotensive rats -potential role of superoxide-induced oxidative stress, Journal of Hypertension, 22(3), 2004, 543-550.

[22]. J.R Prohaska, Changes in $\mathrm{Cu}, \mathrm{Zn}$-Superoxide dismutase, Cytochrome-C oxidase, Glutathione peroxidise and Glutathione transferase activities in copper deficient mice and rats, Journal of Nutrition, 121(3), 1991, 355-363.

[23]. K.B Singh, and S.K Taneja, Hazard effects of excess of zinc in diet, Space Camp Interested Visually Impaired Students,9(4), 2009, 159-165.

[24]. J.J Strain, Newer aspects of micronutrients in chronic diseases: copper, Proceedings of the Nutrition Society, 53(3), 1994, 583-598.

[25]. M.O Parat, M.J Richard, J.C Beani, and A Favier, Involvement of zinc in intracellularoxidant/antioxidant balance, Biological Trace Element Research, 60, 1997, 187-204.

[26]. A Ozturk, A.K Baltaci, R Mogulkoc, E Oztekin, A Sivrikaya, E Kurtoglu, and A Kul,Effects of zinc deficiency and supplementation on malondialdehyde and glutathione levels in blood and tissues of rats performing swimming exercise, Biological Trace Element Research, 94, 2003, 157-166.

[27]. P.L Oteiza, K.L Olin, C.G Fraga, andC.L Keen, Oxidantdefense system in testis from zinc- deficient rats,Proceedings of the Society for Experimental Biology and Medicine,213, 1996, 85-91.

[28]. A.KBaltaci, F Sunar, R Mogulkoc, andEOztekin, Effect of zinc deficiency and supplementation on lipid peroxidation of renal tissue in overioctomized rats,Biological Trace Element Research, 101, 2004, 231-239.

[29]. P Sidhu, M.L Garg, and D.K Dhawan, Protective effects of zinc on oxidative stress enzymes in liver of protein deficient rats, NutriciónHospitalaria, 19(6), 2004, 341-347.

[30]. M.I Yousef, H.A El-Hendy, F.M El-Demardash, andE.I Elagamy, Dietary zinc deficiency induced changes in the activity of enzymes and the levels of free radicals, lipidsand protein electrophoretic behavior in growing rats, Toxicology, 175, 2002, 223-234.

[31]. C.S Bediz, A.K Baltaci,R Mogulkoc,and E Oztekin, Zinc supplementation ameliorates electromagnetic fieldinduced lipid peroxidation in the rat brain,Tohoku Journal ofExperimental Medicine, 208 (2), 2006, 133-140.

[32]. F.A Dawud, E.D Eze, A.A Ardja, A.S Isa, A Jimoh, M Bashiru, andI.S Malgwi, Ameliorative effects of vitamin C and zinc in alloxan-induced diabetes and oxidative stress in wistar rats, Current Research Journal of Biological Sciences, 4(2), 2012, 123-129.

[33]. D.K Dhawan, and A Goel, Protective role of zinc on rat liver function in long term toxicity induced by carbon tetrachloride, Journal of Trace Elements in Experimental Medicine, 7, 1994, 1-9.

[34]. RClaeyssen, M Andriollo-Sanchez, J Arnaud, L Touvard, A Alonso, Y Chancerelle,A.MRoussel, andD Agay,Burn-induced oxidative stress is altered by a lowzinc status: kinetic study in burned rats fed a low zincdiet, Biological Trace Element Research, 126(1), 2008, 80-96. 